\title{
Maize Stem Tissues: Impact of Development on Cell Wall Degradability
}

\begin{abstract}
Grass degradability declines as cell wall and lignin concentrations increase during maturation. The role of tissue development and lignification in decline of stem degradability was examined in maize (Zea mays L.) internodes sampled at 10 stages of growth from early elongation through plant physiological maturity. The fourth elongated internode above ground level was collected from three maize hybrids grown in a 2-yr, replicated field trial at St. Paul, MN. Internode cross-sections and ground samples were incubated in vitro for 24- and 96-h with rumen microbes. Tissue degradation was examined by light microscopy and degradability of cell wall polysaccharide components from ground internodes was determined. All tissues in elongating internodes were completely degradable except for protoxylem vessels, which was the only lignified tissue. After elongation, degradability of all tissues declined markedly except for phloem, which never lignified. Tissues with thick, lignified secondary walls (sclerenchyma and rindregion parenchyma) required longer incubation times for observable degradation. Cell wall polysaccharide components were highly degradable in immature internodes, but degradability declined after elongation and reached a minimum by Sampling Date 8, with glucose and xylose residues having the greatest reductions in degradability. Cell wall polysaccharide degradation was related to lignin concentration and ferulate cross-linking in a complex manner.
\end{abstract}

$\mathrm{M}$ ILK AND MEAT PRODUCTION by ruminant livestock is largely dependent on forages (Galyean and Goetsch, 1993). Because forages generally have high concentrations of cell wall material, degradability of cell walls often determines how much digestible energy ruminants will have available for productive functions. The decline in cell wall degradability of forages associated with maturation is well documented. This reduction in cell wall degradability is thought to be caused primarily by progressively greater lignification of plant cell walls during development (Jung and Deetz, 1993). However, the degree to which the different plant parts and tissues lignify varies dramatically (Wilson, 1993). These tissue-specific differences in lignification may account for the limited negative correlation of lignin concentration with cell wall degradability observed with forage samples of similar maturity.

As grass stems develop, sclerenchyma and the rindregion parenchyma tissues develop thick, lignified cell walls (Wilson, 1993). These lignified grass tissues are degraded slowly, but after extended periods of degradation only a very thin residual wall layer remains un-

H.G. Jung, USDA-ARS Plant Science Res. Unit and U.S. Dairy Forage Res. Center Cluster, Univ. of Minnesota, Dep. of Agronomy and Plant Genetics, 411 Borlaug Hall, 1991 Upper Buford Circle, St. Paul, MN 55108; M.D. Casler, USDA-ARS U.S. Dairy Forage Res., 1925 Linden Drive West, Madison, WI 53706. Received 2 Mar. 2006. *Corresponding author (jungx002@umn.edu).

Published in Crop Sci. 46:1801-1809 (2006).

Forage \& Grazinglands

doi:10.2135/cropsci2006.02-0086

(c) Crop Science Society of America

677 S. Segoe Rd., Madison, WI 53711 USA degraded (Engels, 1989). This pattern of extensive degradation of thick-walled, lignified tissues is markedly different than what has been observed in legumes. Xylem tissue of alfalfa (Medicago sativa L.) stems has thick, heavily lignified walls and is virtually nondegradable (Jung and Engels, 2002). The reason for this difference among these forages in degradability of lignified tissues is unclear. Legumes generally have higher concentrations of lignin than do grasses of similar maturity, although some of this reported difference results from the poor recovery of grass lignin in the acid detergent lignin method (Hatfield et al., 1994). Both types of forages undergo a shift in composition from primarily guaiacyl-type lignin to mixed syringyl-guaiacyl lignin during maturation (Jung and Deetz, 1993). While lignified legume and grass cell walls are both rich in cellulose and xylans, grasses contain very little pectin (Moore and Hatfield, 1994) and legumes do not contain appreciable amounts of ferulates (Jung and Deetz, 1993).

Early studies with a synthetic lignin model (polyeugenol) complex with cellulose indicated that crosslinking was necessary for lignin to inhibit cellulose degradation by both isolated cellulase and rumen microbes (Gressel et al., 1983; Jung and Ralph, 1990). Both ferulate monomers and dimers have been identified as being cross-linking agents in grasses (Iiyama et al., 1990; Ralph et al., 1992, 1994). Ralph et al. (1995) demonstrated that ferulate esters in perennial ryegrass (Lolium perenne L.) act as the initiation site where lignin polymerization begins. Therefore, ferulate-mediated cross-links, formed during cell wall development, have the potential to influence cell wall degradability. In a series of studies using a maize (Zea mays L.) cell culture model system, Grabber and coworkers demonstrated that cross-linking of arabinoxylan to lignin by ferulate monomers and dimers reduced polysaccharide degradability by isolated enzymes (Grabber et al., 1995, 1998a, 1998b). In maize basal-stem internodes collected at silking, both Klason lignin and ferulate ether (the only form of cross-linking that can currently be quantified) concentrations were only weakly negatively correlated with cell wall degradability (Jung and Buxton, 1994). However, in elongating maize internodes, ferulate ether concentration was strongly negatively correlated with cell wall degradability, whereas degradation of postelongation internodes was more strongly correlated with Klason lignin concentration (Jung et al., 1998). Neutral detergent fiber degradability of smooth bromegrass (Bromus inermis Leyss) plants, selected for divergent ferulate ether and Klason lignin concentrations, was negatively impacted by both cell wall components. However, these components were at least partially independent of one another in their effects, and ferulate ethers

Abbreviations: LSD, least significant difference. 
had a larger relative impact on fiber degradation than did Klason lignin (Casler and Jung, 1999).

On the basis of the observation that thick, lignified maize secondary cell walls can be extensively thinned by extended ruminal degradation to leave a thin-walled residual wall structure, Engels (1989) suggested that this recalcitrant layer represents the original primary wall of these cells. Wilson and Mertens (1995) hypothesized that such nondegradable cell wall layers would prevent access by rumen microbes to potentially degradable cell walls in adjacent plant cells that had not been ruptured by chewing or grinding. These results suggest that lignin's impact on degradability of forage cell walls is not directly related to concentration. However, there are many reports in the literature of strong, quantitative negative correlations between cell wall degradability and lignin concentration (Jung and Deetz, 1993). The challenge is to reconcile and interpret these seemingly conflicting cell wall degradability data from microscopic observations with the results for ground forage tissues.

The objective of the study reported here was to relate changes in degradability of grass cell walls observed for individual stem tissues during development with quantitative data for cell wall polysaccharide degradation, and clarify how ferulate cross-linking and lignin impact degradability. A single, defined internode of maize was used as a model for grasses. Three genetically diverse maize hybrids were included in the study to ensure that conclusions were not genotype specific. Data on cell wall accumulation, tissue development, and compositional changes during internode growth were previously reported (Jung, 2003; Jung and Casler, 2006).

\section{MATERIALS AND METHODS}

\section{Plant Material}

Details of the growth and sampling of maize for this study were reported by Jung and Casler (2006). Briefly, three maize hybrids (A632 × A619, A679 × FR481, and Mycogen 2677, referred to as hybrids 632, 679, and 2677, respectively) were grown at St. Paul, MN, in 1998 and 1999 in replicated field plots. The fourth elongated internode above the soil surface was sampled at 10 stages of development beginning when this internode was 10 to $15 \mathrm{~mm}$ in length and concluded at full physiological maturity (mature grain) of the maize plants. Number of maize plants collected at each sampling date declined from 44 plants at the first sampling date to eight plants for the final four sampling dates. Four internodes from each hybrid and field plot per sampling date were immediately placed in $50 \%$ ethanol:water (v/v) for preservation and use in subsequent microscopic evaluations. The remaining sampled internodes were frozen before lyophilization, ground to pass a 1-mm screen in a cyclone-type mill, and used for analysis of chemical composition and in vitro degradation by rumen microorganisms. Summary data for internode cell wall concentration and composition at each of the 10 sampling dates are shown in Table 1.

\section{In Vitro Degradation}

Degradability of cell wall polysaccharides was determined by in vitro incubation with rumen microbes. Dried and ground internode samples $(200 \mathrm{mg})$ were incubated with $30 \mathrm{~mL}$ of a $20 \%$ rumen fluid: buffer (McDougall, 1948) mixture (v/v). Rumen fluid was collected approximately 20-h post-feeding from a rumen-fistulated, lactating Holstein cow fed a total mixed ration containing alfalfa hay, maize silage, and concentrates. Incubations were conducted in 50-mL disposable centrifuge tubes with screw caps. Samples were incubated at $39^{\circ} \mathrm{C}$ in a water bath for 24 and $96 \mathrm{~h}$ with periodic agitation. At the conclusion of incubations, the entire contents of the centrifuge tubes were frozen at $-20^{\circ} \mathrm{C}$ and lyophilized before analysis of the nondegraded residual cell wall material. Dried residues from the in vitro incubations were analyzed for remaining cell wall polysaccharide components (glucose, xylose, arabinose, galactose, mannose, rhamnose, fucose, and uronic acids) by the Uppsala Dietary Fiber procedure (Theander et al., 1995). Glucuronic acid was used as the standard for the colorimetric determination of uronic acids (Ahmed and Labavitch, 1977). Amount of cell wall polysaccharide material added to the incubations with the rumen fluid inoculum was determined by incubating centrifuge tubes containing only the rumen fluid:buffer inoculum. Degradability of total cell wall polysaccharides (sum of all monosaccharide residues) and individual components were calculated using the data for cell wall composition of each internode sample (Jung and Casler, 2006).

Table 1. Summary cell wall concentration and composition data for the fourth elongated internode above ground level of maize sampled at 10 stages of development. Data are means for three hybrids grown at St. Paul, MN, in 1998 and 1999 (Jung and Casler, 2006).

\begin{tabular}{|c|c|c|c|c|c|c|c|c|c|c|}
\hline \multirow[b]{2}{*}{ Trait $\dagger$} & \multicolumn{10}{|c|}{ Sampling date } \\
\hline & 1 & 2 & 3 & 4 & 5 & 6 & 7 & 8 & 9 & 10 \\
\hline \multirow{3}{*}{ Cell wall } & \multicolumn{10}{|c|}{$\mathrm{g} \mathrm{kg}^{-1}$ organic matter } \\
\hline & 307 & 302 & 320 & 429 & 534 & 677 & 733 & 653 & 551 & 593 \\
\hline & \multicolumn{10}{|c|}{$\mathrm{g} \mathrm{kg}^{-1}$ cell wall } \\
\hline Glucose & 349 & 391 & 445 & 510 & 523 & 501 & 482 & 460 & 465 & 463 \\
\hline Xylose & 180 & 182 & 190 & 224 & 244 & 239 & 233 & 226 & 216 & 220 \\
\hline Arabinose & 100 & 94 & 86 & 56 & 34 & 23 & 18 & 18 & 20 & 22 \\
\hline Galactose & 70 & 62 & 55 & 33 & 17 & 10 & 8 & 8 & 10 & 11 \\
\hline Mannose & 38 & 36 & 33 & 22 & 15 & 10 & 8 & 8 & 10 & 9 \\
\hline UA & 145 & 127 & 115 & 80 & 52 & 40 & 35 & 35 & 38 & 38 \\
\hline KL & 109 & 98 & 65 & 56 & 86 & 136 & 165 & 195 & 186 & 184 \\
\hline FA-esters & 1.20 & 1.62 & 2.76 & 5.57 & 5.96 & 5.08 & 4.44 & 4.57 & 5.25 & 5.12 \\
\hline FA-ethers & 0.41 & 0.57 & 0.43 & 1.99 & 3.50 & 4.81 & 5.52 & 4.81 & 5.17 & 4.77 \\
\hline \multirow[t]{2}{*}{ PCA } & 0.84 & 0.84 & 1.12 & 7.59 & 14.64 & 23.46 & 29.65 & 32.65 & 34.90 & 35.04 \\
\hline & \multicolumn{10}{|c|}{ Normalized to guaiacol yield } \\
\hline S/G ratio & 0.08 & 0.03 & 0.02 & 0.55 & 0.84 & 1.37 & 1.74 & 1.87 & 2.15 & 2.24 \\
\hline
\end{tabular}

$\dagger$ UA, uronic acids; KL, Klason lignin, FA-esters, ferulate esters; FA-ethers, ferulate ethers; PCA, p-coumarate esters; S/G ratio, syringyl-to-guaiacyl monolignol ratio. 

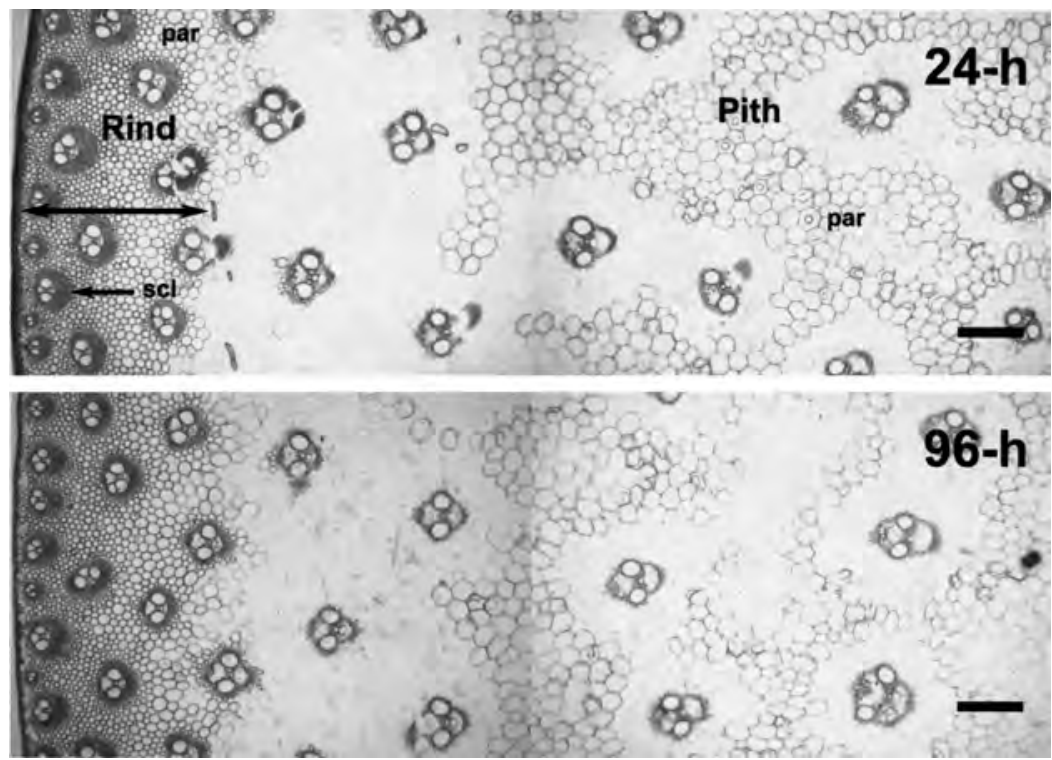

Fig. 1. Micrographs showing stem internode tissues of maize hybrid 632 at full physiological maturity (mature grain, Sampling Date 10) remaining after in vitro degradation by rumen microbes for 24 or $96 \mathrm{~h}$. The images were created by combining two adjacent fields of view. The double-ended arrow indicates the approximate width of the rind region that remained nondegraded. Bar $=500 \mu \mathrm{m}$; par, parenchyma; scl, sclerenchyma.

Degradability of individual stem tissues was determined from thin cross-sections $(100 \mu \mathrm{m})$ prepared from the ethanolpreserved internodes (see below). Sections were mounted on slides using double-sided tape and incubated for 24 and $96 \mathrm{~h}$ with the same rumen fluid: buffer inoculum used for the ground samples. After completion of the incubations the slides were gently rinsed in tap water and then stored in 50\% ethanol until evaluated microscopically.

\section{Microscopic Analysis}

On the basis of the differences observed among sampling dates and maize hybrids for cell wall polysaccharide degradability of ground internode samples, specific internodes preserved in $50 \%$ ethanol were selected for microscopic evaluation. Cross-sections $100 \mu \mathrm{m}$ in thickness were made from the middle of selected internodes. A sliding-type microtome was used for sectioning at least 12 cross-sections from each internode, which were stored in $50 \%$ ethanol. Randomly chosen sections were used for evaluation of cell wall development of individual tissues (Jung and Casler, 2006) and additional sections were used for in vitro degradation by rumen microbes (see above). Both degraded and non-degraded control sections were observed by light microscopy. A Spot digital camera ${ }^{1}$ (Diagnostic Instruments, Inc., Sterling Heights, MI) was used to collect images. Digital images were processed with Adobe Photoshop (Adobe Systems Inc., San Jose, CA) to improve contrast and annotate figures. For Sampling Date 10, internodes from each maize hybrid, for all field plots in both years, linear measurements were made of the width of rind tissue remaining after degradation of internode cross-sections and the width of the degraded parenchyma tissue gap created during the in vitro ruminal incubation.

\section{Statistical Analysis}

Measurements of cell wall degradability were done in duplicate. Mean degradability data for internode samples were

\footnotetext{
${ }^{1}$ Mention of a proprietary product does not constitute a recommendation or warranty of the product by the USDA or the University of Minnesota, and does not imply approval to the exclusion of other suitable products.
}

analyzed by mixed models analysis, using a randomized complete block design combined over years with sampling dates as repeated measures. The repeated measures were modeled from unstructured, compound symmetric, and heterogeneous compound symmetric covariance structures with the best structure chosen on the basis of Akaike's Information Criterion (SAS Institute Inc., Cary, NC). Rind tissue width and parenchyma tissue gap width in degraded cross-sections were also analyzed by mixed models, excluding the repeated measures. Hybrid and sampling date were treated as fixed effects, while year and block were treated as random effects. Means of fixed effects were compared using Fisher's least-significant difference (LSD). Mean squares used in the LSD calculations were synthesized as linear combinations of variance components for all random effects that contributed to a particular fixed effect (Littel et al., 1996). All effects presented in the Results section were significant at the $P<0.05$ probability level. Simple correlations and regression analyses were done using the PROC CORR and PROC REG procedures of SAS ver. 9.1 software package.

\section{RESULTS Tissue Degradation}

Overviews of the stem tissues typically remaining after 24- or 96-h degradation by rumen microbes for maize internodes from Sampling Date 10 are shown in Fig. 1. For all the maize hybrids, the pith parenchyma tissue immediately interior to the rind region of the stem was virtually completely degraded within $24 \mathrm{~h}$. Parenchyma located in the more central pith region was less degradable, with a general pattern of the nearest parenchyma cell layers surrounding vascular bundles being completely degraded and less degradation of parenchyma cells farther removed from the vascular tissue. Some additional degradation of parenchyma tissue was often observed after $96 \mathrm{~h}$ of exposure to rumen microbes (Fig. 1), but this increase in degradation was less obvious than suggested by the increase in degradation found for the 
ground internode samples exposed to longer incubation times (see below). While higher magnification observations showed some thinning of sclerenchyma tissue from Sampling Date 10 internodes (Fig. 2), complete degradation of this tissue was never observed in postelongation internodes. No obvious differences in the general pattern of stem tissue degradation were noted among the maize hybrids at any of the developmental stages.

Linear width measurements of maize rind remaining in internode cross-sections from Sampling Date 10 after 24- and 96-h degradation (Fig. 1) indicated that the width of the residual rind tissue did not differ among hybrids for either incubation period. The size of the degraded parenchyma gap immediately inside the rind region did not differ among the hybrids after the 24-h incubation, but hybrid differences were observed after a 96-h incubation $(1.94,2.39$, and $4.13 \mathrm{~mm}, \mathrm{LSD}=1.54$; for hybrids 632 , 679 , and 2677, respectively). However, these measurements should be viewed with some caution because of the subjective nature of decisions concerning the average width of these tissue residues in a section.
Figure 2 illustrates in greater detail the degradation of rind-region stem tissues from internodes collected at Sampling Dates 4 (late elongation) and 10 (late postelongation). After $24 \mathrm{~h}$ of degradation by rumen microbes, most tissues from elongating internodes were still recognizable; however, all tissues except for protoxylem vessels showed clear signs of extensive degradation (Fig. 2b). After 96 h, the only identifiable cell wall structure remaining in elongating internodes was the lignified rings in protoxylem vessels (Fig. 2c). These lignified structures were visible as separate, concentric rings because the surrounding cell wall material in protoxylem vessel cells had been degraded away. This same pattern was observed for all sampling dates before elongation was complete (samples one through five). After the end of the elongation developmental phase, the amount of nondegradable stem tissue increased rapidly. At the final sampling date, phloem was the only rind-region tissue completely degraded (Fig. 2e and f). However, some thinning of sclerenchyma cell walls could be discerned after 24-h incubations and clear signs
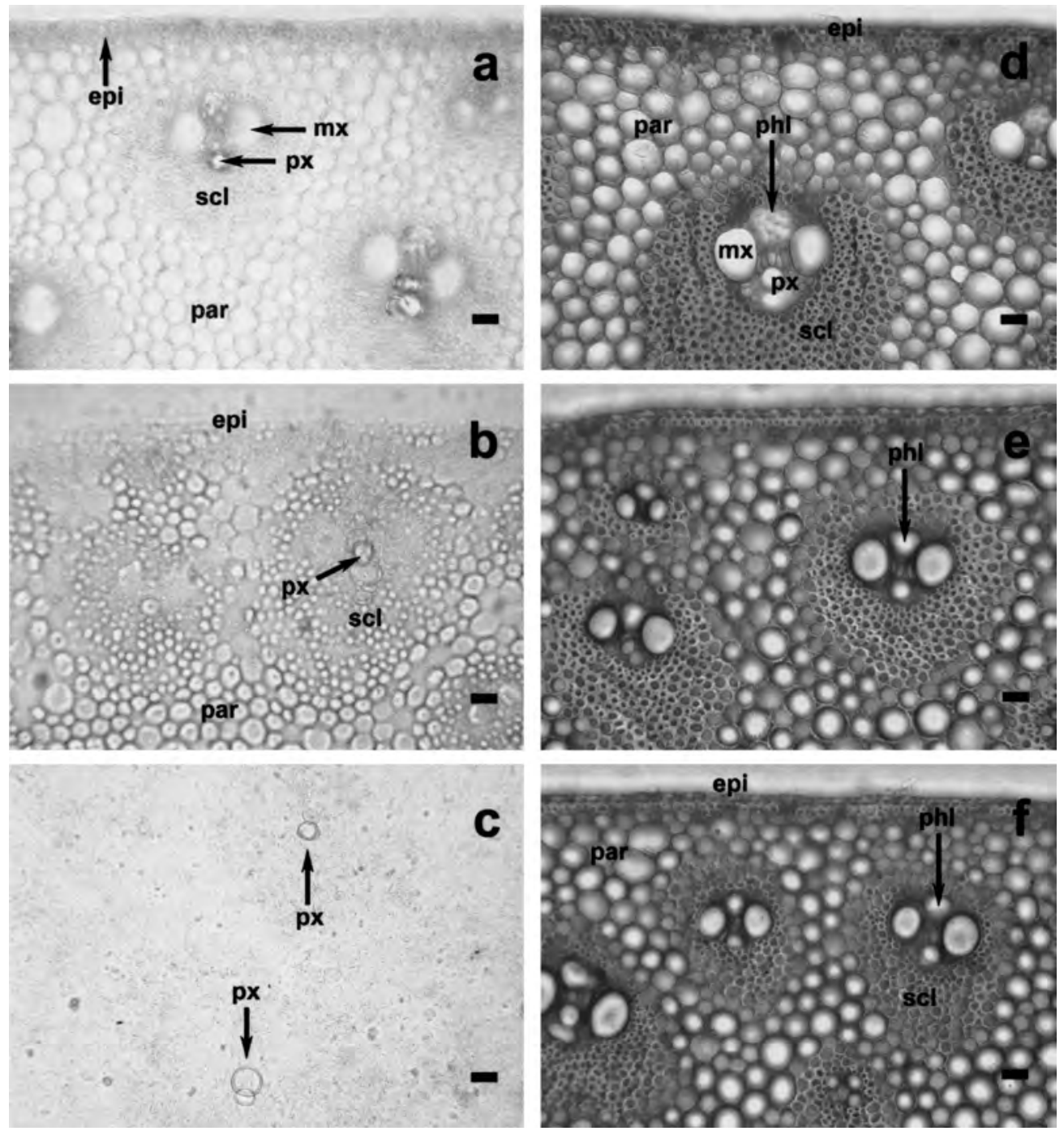

Fig. 2. Rind-region tissues from maize hybrid 679 at Sampling Dates 4 (a) and 10 (d) and after in vitro degradation by rumen microorganisms for 24

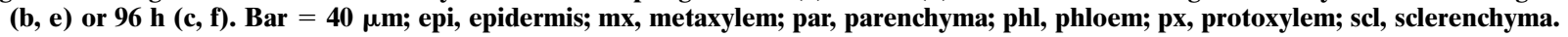




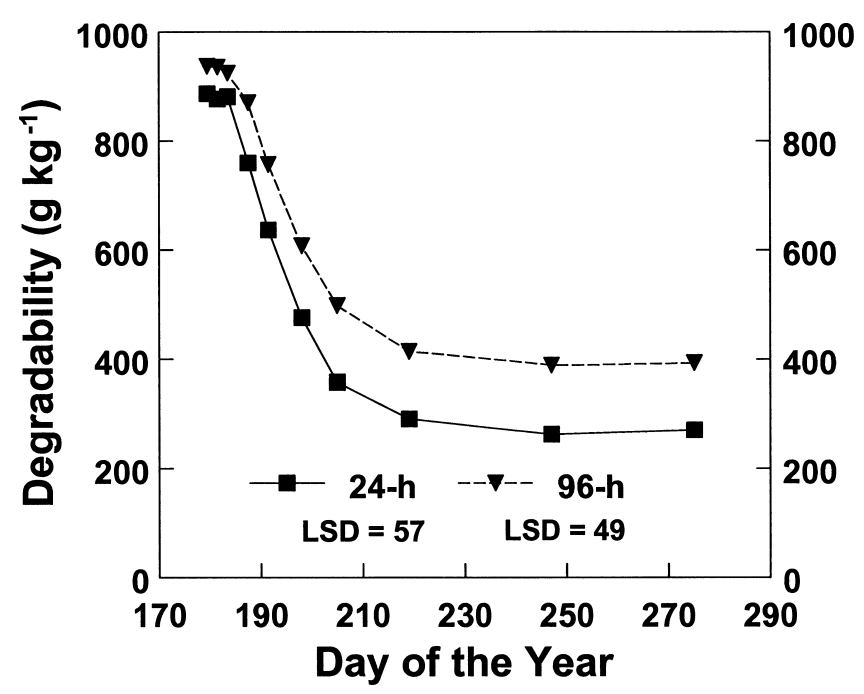

Fig. 3. Degradability of total cell wall polysaccharides after 24- and 96-h in vitro incubations with rumen microorganisms for the fourth elongated internode above ground level, averaged across maize hybrids 632, 679, and 2677, sampled at 10 stages of development. The arrow located between the fifth and sixth sampling dates represents the approximate time when elongation of the internodes ceased. LSD, least significant difference $(P<0.05)$.

of sclerenchyma wall thinning by degradation were seen after 96 h. Maize hybrid 632 exhibited a characteristic degradation pattern for Sampling Date 10 internodes where some of the rind-region parenchyma cells immediately adjacent to the epidermis were completely degraded after $96 \mathrm{~h}$ (Fig. 1). This complete degradation of subepidermal parenchyma was not observed for the other two hybrids.
For vascular bundles located in the pith region, degradation patterns followed those observed for rind tissues. All tissues, except protoxylem vessels, were completely degraded from elongating internodes, whereas only phloem tissue was completely degraded in internodes from Sampling Date 10 (data not shown). Thinning of the sclerenchyma cell walls occurred for pith-region vascular bundles from post-elongation internodes as observed for this tissue in the rind. Although pith parenchyma tissue had thinner walls than rind-region parenchyma, only those parenchyma cells immediately adjacent to the vascular bundles were completely degraded in late stages of post-elongation development.

\section{Cell Wall Polysaccharide Degradation}

Because cell wall rhamnose and fucose concentrations were extremely low (0-7 $\mathrm{g} \mathrm{kg}^{-1}$ cell wall), degradability values for these monosaccharides could not be determined with accuracy. However, the amount of these monosaccharides in the maize internodes before and after in vitro degradation by rumen microbes was determined and used in the calculation of total cell wall polysaccharide degradability.

An appraisal of the degradability patterns in Fig. 3 clearly shows that, as expected, extending the incubation time from 24 to $96 \mathrm{~h}$ increased degradation of total cell wall polysaccharides at all developmental stages. Prolonged incubation increased degradation by almost half for the internodes at Sampling Date 10. A similar pattern of increasing degradation with prolonged in vitro incubations was found for all individual monosaccharides, although to different degrees (Fig. 4). The more

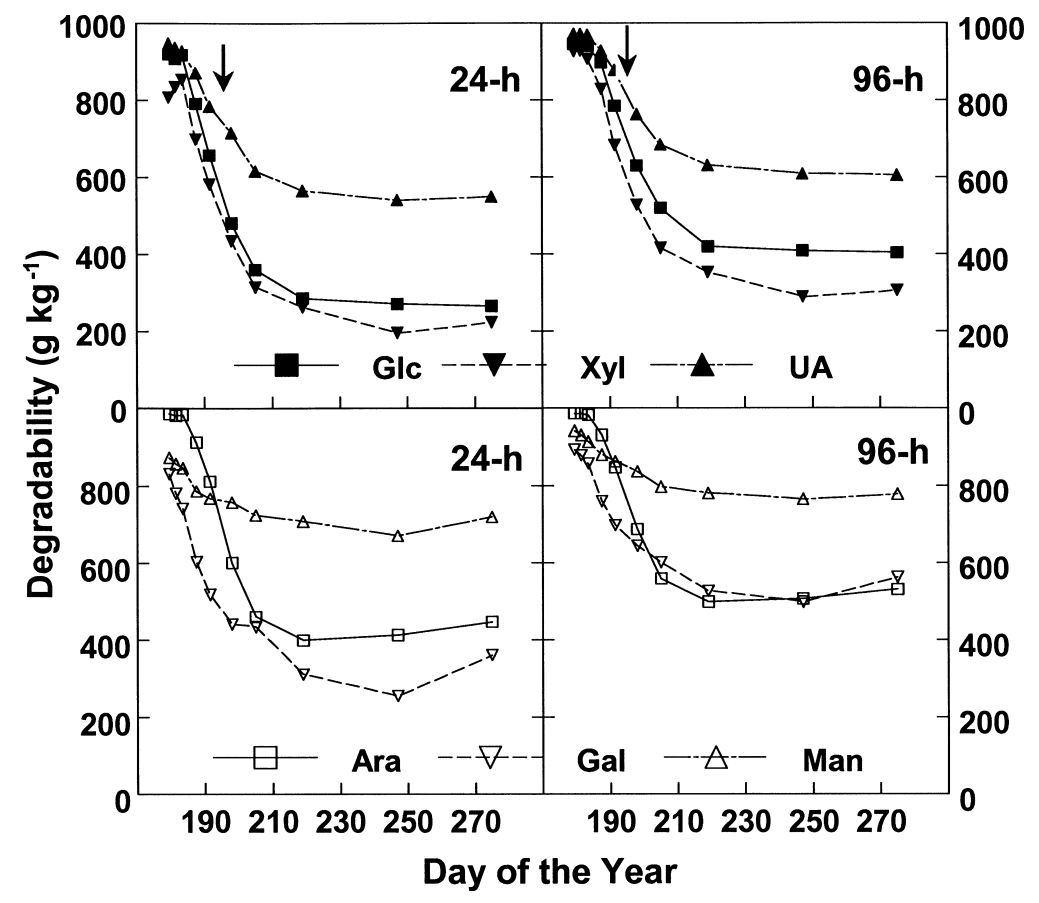

Fig. 4. In vitro ruminal degradability of cell wall polysaccharide component sugars after 24- (a, c) and 96-h (b, d) incubations for maize stem internodes, averaged across three hybrids, as influenced by stage of development. The arrow located between the fifth and sixth sampling dates represents the approximate time when elongation of the internodes ceased. Least significant difference values $(P<0.05)$ for $24-$ and 96-h degradability, respectively, were glucose $=55,48$; xylose $=128,81$; uronic acids $=37,30$; arabinose $=41,42 ;$ galactose $=54,41$; mannose $=$ 48, 19. Ara, arabinose; Gal, galactose; Glc, glucose; Man, mannose; UA, uronic acids; Xyl, xylose. 
highly degradable monosaccharides in post-elongation internodes (mannose and uronic acids) increased in degradation because of prolonged incubation to a lesser extent than did the most poorly degradable monosaccharides. However, the greatest increase in degradation was observed for galactose, which almost doubled after $96 \mathrm{~h}$ compared with a 24-h incubation. The impact of incubation time on total cell wall polysaccharide degradation mirrored the less degradable monosaccharide components (glucose and xylose) rather than more degradable monosaccharides. This was not unexpected given that glucose and xylose were always the most abundant monosaccharide constituents of the maize cell walls.

Statistical analysis of the degradability data for ground internodes indicated that the hybrids did not differ for degradability of any cell wall polysaccharide component, whereas degradability of all components was significantly affected by sampling date (Table 2). The interaction of hybrid $\times$ sampling date was only significant for degradability of uronic acids after $24 \mathrm{~h}$ and mannose after $96 \mathrm{~h}$. The differences among hybrids for these two degradability measures were inconsistent among sampling dates (data not shown). The remaining presentation of results will focus on the differences among developmental stages at the 10 sampling dates.

As the development of maize stem internodes advanced across sampling dates, degradability of total cell wall polysaccharides declined dramatically (Fig. 3). Internodes from the first sampling date were highly degradable ( $887 \pm 9$ and $937 \pm 5 \mathrm{~g} \mathrm{~kg}^{-1}$ for 24 - and 96 -h total cell wall polysaccharide degradability, respectively), but their degradability began to decline even before elongation was complete. Cell wall polysaccharide degradation did not differ among maize internodes from the first three sampling dates and then declined significantly at each subsequent sampling until the eighth sampling date when total cell wall polysaccharide degradability

Table 2. Mixed models analysis results for fixed effects on in vitro ruminal degradability of total cell wall polysaccharides and component monosaccharide residues after incubation times of 24 and $96 \mathrm{~h}$ of the fourth elongated internode above ground level from three maize hybrids grown at St. Paul, MN, in 1998 and 1999, sampled at 10 developmental stages.

\begin{tabular}{lccc}
\hline & \multicolumn{3}{c}{ Fixed effects } \\
\cline { 2 - 4 } Trait & Hybrid & Sampling date & Hybrid $\times$ date \\
\hline Degrees of freedom & $\mathbf{2}$ & $\mathbf{9}$ & $\mathbf{1 8}$ \\
24-h Degradability & NS $\dagger$ & $* * *$ & NS \\
Total & NS & $* * *$ & NS \\
Glucose & NS & $* * *$ & NS \\
Xylose & NS & $* * *$ & NS \\
Arabinose & NS & $* * *$ & NS \\
Galactose & NS & $* * *$ & NS \\
Mannose & NS & $* * *$ & $* * *$ \\
Uronic acids & NS & $* * *$ & NS \\
96-h Degradability & NS & $* * *$ & NS \\
Total & NS & $* * *$ & NS \\
Glucose & NS & $* * *$ & NS \\
Xylose & NS & $* * *$ & NS \\
Arabinose & NS & $* * *$ & $*$ \\
Malactose & NS & $* * *$ & NS \\
Mannose & Uronic acids & &
\end{tabular}

* Probability level of 0.05 .

**** Probability level of 0.001

$\dagger$ NS, nonsignificant $(P>0.05)$. reached a plateau. The same pattern of differences among sampling dates for cell wall polysaccharide degradability was observed after 24 and $96 \mathrm{~h}$.

Degradability of the individual monosaccharide components of the cell wall followed the same general pattern of decline with advancing development as did total cell wall polysaccharide degradation (Fig. 4); however, the degree to which degradability declined varied markedly among the monosaccharides. Uronic acids and mannose appeared to decline less in degradability with development than the other monosaccharides, with mannose clearly showing the least change in degradation because of development of any monosaccharide. For example, the reduction in 24-h degradability of mannose between the first and tenth sampling dates was only 23\% (from $874 \pm 4$ to $671 \pm 30 \mathrm{~g} \mathrm{~kg}^{-1}$ ), whereas xylose degradation declined by $72 \%$ (from $808 \pm 47$ to $223 \pm 25 \mathrm{~g} \mathrm{~kg}^{-1}$ ) over this same interval.

\section{Relationships of Cell Wall Composition and Degradability}

All measures of cell wall degradability (total polysaccharides and individual monosaccharides) were strongly and positively correlated with one another (data not shown). This observation was true when all data for individual field plots were included or if mean data for year $\times$ hybrid $\times$ sampling date or hybrid $\times$ sampling date or only sampling date means were used in the analysis. For the sampling date mean data $(N=10)$, correlations ranged from $r=0.94(P<0.001)$ for 24-h degradability of mannose with $96-\mathrm{h}$ degradability of uronic acids to $r=0.9998(P<0.0001)$ for 24 -h degradabilities of glucose and total polysaccharides.

Because the measures of cell wall polysaccharide degradability were strongly correlated, most measures of degradability had significant correlations with cell wall concentration and composition. This is illustrated in Table 3 for 24- and 94-h degradabilities of total cell

Table 3. Simple linear correlation coefficients for cell wall concentration and composition with 24- and 96-h degradability of total cell wall polysaccharides for the fourth elongated internode above ground level. Data $(N=10)$ used were the means for 10 stages of development averaged over three hybrids, sampled in 1998 and 1999 from replicated field plots.

\begin{tabular}{|c|c|c|}
\hline Trait $\dagger$ & $\begin{array}{c}\text { 24-h } \\
\text { Degradability }\end{array}$ & $\begin{array}{c}\text { 96-h } \\
\text { Degradability }\end{array}$ \\
\hline Cell wall, $\mathrm{g} \mathrm{kg}^{-1}$ organic matter & $-0.87 * * *$ & $-0.84 * *$ \\
\hline Klason lignin, $\mathrm{g} \mathrm{kg}^{-1}$ cell wall & $-0.90 * * *$ & $-0.92 * * *$ \\
\hline Glucose, $\mathbf{g ~ k g}^{-1}$ cell wall & $-\mathbf{0 . 4 7}$ & $-\mathbf{0 . 4 1}$ \\
\hline Xylose, $\mathrm{g} \mathrm{kg}^{-1}$ cell wall & $-0.66^{*}$ & -0.60 \\
\hline Arabinose, $\mathrm{g} \mathrm{kg}^{-1}$ cell wall & $0.93 * * *$ & $0.90 * * *$ \\
\hline Galactose, $\mathrm{g} \mathrm{kg}^{-1}$ cell wall & $0.91 * * * *$ & $\mathbf{0 . 8 8} * * *$ \\
\hline Mannose, $\mathbf{g ~ k g}^{-1}$ cell wall & $0.93 * * *$ & $0.90 * * *$ \\
\hline Rhamnose, $\mathrm{g} \mathrm{kg}^{-1}$ cell wall & $0.87 * * *$ & $\mathbf{0 . 8 3} * *$ \\
\hline Fucose, $\mathbf{g ~ k g}^{-1}$ cell wall & 0.54 & 0.52 \\
\hline Uronic acids, $\mathrm{g} \mathrm{kg}^{-1}$ cell wall & $0.92 * * *$ & $0.89 * * *$ \\
\hline PCA, $\mathbf{g ~ k g}^{-1}$ cell wall & $-1.00 * * *$ & $-1.00 * * *$ \\
\hline FA-esters, $\mathrm{g} \mathrm{kg}^{-1}$ cell wall & $-0.66^{*}$ & $-\mathbf{0 . 6 1}$ \\
\hline FA-ethers, $\mathrm{g} \mathrm{kg}^{-1}$ cell wall & $-0.96 * * *$ & $-0.94 * * *$ \\
\hline S/G Ratio & $-\mathbf{1 . 0 0} * * *$ & $-0.99 * * *$ \\
\hline $\begin{array}{l}* \text { Probability level of } \mathbf{0 . 0 5} \text {. } \\
* * \text { Probability level of } \mathbf{0 . 0 1} \text {. } \\
* * * \text { Probability level of } \mathbf{0 . 0 0 1} \text {. }\end{array}$ & & \\
\hline
\end{tabular}


wall polysaccharides. Both 24- and 96-h degradabilities were strongly, negatively correlated with total cell wall concentration and most measures of cell wall lignification (Klason lignin, esterified $p$-coumarate, etherified ferulate, and syringyl-to-guaiacyl ratio). Xylose and esterified ferulate concentrations of the cell wall were negatively correlated with 24 -h total cell wall polysaccharide degradability but not 96-h degradation. Total cell wall polysaccharide degradability was not correlated with either the most or least abundant cell wall monosaccharides (glucose and fucose, respectively). All of the other cell wall monosaccharides were positively correlated with total cell wall polysaccharide degradation.

The relationships of two key elements in cell wall lignification (Klason lignin and ferulate ether cross-links) with degradability are shown in Fig. 5. While degradability of total cell wall polysaccharides was strongly negatively related with Klason lignin concentration, internodes from the first three sampling dates did not follow the same relationship as later samples. The opposite pattern was observed for ferulate ethers where samples eight through 10 did not follow the relationship for less developed internodes. While the relationship of Klason lignin with degradability was linear, the relationship of degradability with ferulate ethers was curvilinear where the negative impact of ferulate ether cross-links appeared to increase as ferulate ether concentrations rose during development, although the oldest internodes deviated from this pattern (Fig. 5).

\section{DISCUSSION}

Extensive but incomplete degradation of lignified, thick-walled maize tissues was seen in the current study for sclerenchyma and rind-region parenchyma of old internodes. This result is in agreement with a similar observation by Engels (1989). Because most of the plant's lignin is deposited in degradable, thick secondary walls of maize internodes (Jung, 2003), these observations support the concept that lignin is not strictly a quantitative barrier to degradation. However, in the current study strong negative correlations of Klason lignin concentration with cell wall degradability of ground samples were observed for post-elongation internodes, suggesting lignin was a quantitative barrier to microbial degradation of maize tissues. An explanation for these seemingly conflicting observations may be possible by considering the process of lignification during stem tissue development.

The apparent lack of a negative impact by lignin on cell wall polysaccharide degradation of very young, elongating internodes from Sampling Dates 1 to 3 (Fig. 5a) can be explained by the strict localization of lignin to protoxylem vessel cells, as seen in thin sections taken from elongating internodes (Jung and Casler, 2006). All tissues were completely degradable in these elongating internodes with the exception of the lignified ring structure from protoxylem vessels (Fig. 2c). That these lignified ring structures from protoxylem vessels were the only nondegradable tissue of elongating maize internodes agrees with observations for stem protoxylem vessels in elongating alfalfa internodes (Jung and Engels, 2002). The relatively high Klason lignin concentration of maize internodes at Sampling Date 1 (109 g $\mathrm{kg}^{-1}$ cell wall) suggests that the actual lignin concentration of the protoxylem vessel ring structures must have been extremely high because the cell walls of only this tissue contained all the lignin present in the internode (Jung and Casler, 2006).

Cell wall polysaccharide degradability of ground maize internodes did not begin to decline until Sampling Date 4. While phloroglucinol-stained thin sections taken from the middle of these elongating internodes did not show the presence of lignin, other than in protoxylem vessels, it would be expected that the older cells closer to the top of the internode may have completed elongation

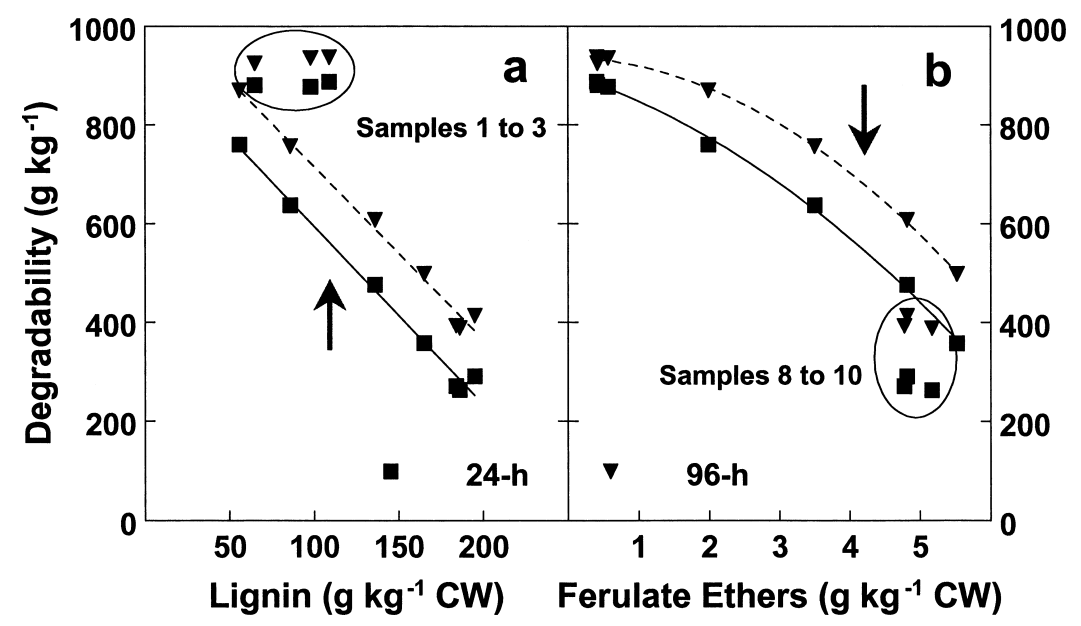

Fig. 5. Relationships of total cell wall polysaccharide degradability with Klason lignin (a) and ferulate ether (b) concentrations for maize stem internodes, averaged across three hybrids and $2 \mathrm{yr}$, after 24- $(\square)$ and 96-h $(\nabla)$ in vitro ruminal incubations for 10 sampling dates. The arrow located between the fifth and sixth sampling dates represents the approximate time when elongation of the internodes ceased. Bars represent one standard error of the mean. Absence of error bars indicates that the standard error was smaller than the size of the data symbol. Linear regressions were calculated for degradability with Klason lignin $\left(24 \mathrm{~h}=956-3.61 \mathrm{KL}, r^{2}=0.99 ; 96 \mathrm{~h}=1067-3.51 \mathrm{KL}, r^{2}=0.99\right)$ and polynomial regressions of degradability with ferulate ethers $\left(24 \mathrm{~h}=903-46.00 \mathrm{FE}-9.29 \mathrm{FE}^{2}, r^{2}=0.998 ; 96 \mathrm{~h}=937-4.66 \mathrm{FE}-13.45 \mathrm{FE}, r^{2}=\right.$ 0.999). Sampling Dates 1 through 3 and 8 through 10 were excluded from the regressions for Klason lignin and ferulate ethers, respectively. 
and begun the post-elongation, secondary wall deposition process by this sampling date. Morrison et al. (1994) reported that lignification had begun in the top third of an elongating maize internode by Day 6 of a 13-d elongation period. The middle third of the maize internode did not contain more acid detergent lignin than the bottom third of the internode until Day 9 of elongation (Morrison et al., 1994). Therefore, from Sampling Date 4 until internode elongation was complete (between Sampling Dates 5 and 6), the internodes contained a mixture of elongating and post-elongation tissues, which may obscure the relationship between lignification and cell wall degradability of ground tissues.

From Sampling Date 4 (later stage of elongation) through the final sample, a significant negative correlation was found for Klason lignin concentration with cell wall degradability. A negative relationship of ferulate cross-linking (measured as ferulate ether concentration) with cell wall degradability was also observed for elongating internodes and during early post-elongation development but not with the oldest internode samples. Jung et al. (1998) had found that ferulate cross-linking was negatively correlated with cell wall degradability of elongating but not post-elongation, maize internodes. These authors postulated that the impact of ferulate cross-links on cell wall degradability became obscured in post-elongation maize internodes because of relatively greater rates of lignin deposition than ferulate deposition in the older internodes. During development of maize internodes, lignin was deposited at a greater rate than ferulates after elongation had ended, although all cell wall deposition ceased in this internode by the ninth sampling date (Jung, 2003). Therefore, deciphering the role of ferulate cross-links on cell wall degradability on the basis of their concentration in the cell walls of mature stem tissues is difficult.

Degradability of artificially lignified maize primary cell walls was increased when the number of ferulate cross-links was decreased by including an inhibitor of ferulic acid biosynthesis during growth of maize cells in suspension culture (Grabber et al., 1995, 1998a, 1998b). When the frequency of ferulate ether cross-links was expressed as a proportion of the Klason lignin concentration in maize internodes, the relationship with total cell wall polysaccharide degradability had a very distinctive pattern (Fig. 6). As the concentration of ferulate cross-links of lignin to arabinoxylan increased during internode elongation, cell wall degradability declined. After the concentration of ferulate cross-links per unit lignin reached a maximum just before the end of elongation, the frequency of cross-linking declined during development of stem tissues post-elongation. As a result, the relationship for frequency of ferulate cross-links to lignin with degradability shifted from a negative relationship during elongation to a positive relationship post-elongation. This observation may suggest an explanation for why lignified secondary walls of maize are potentially degradable, whereas the original primary wall is nondegradable.

Ferulate ester concentration of cell wall material in maize internodes increased throughout the elongation

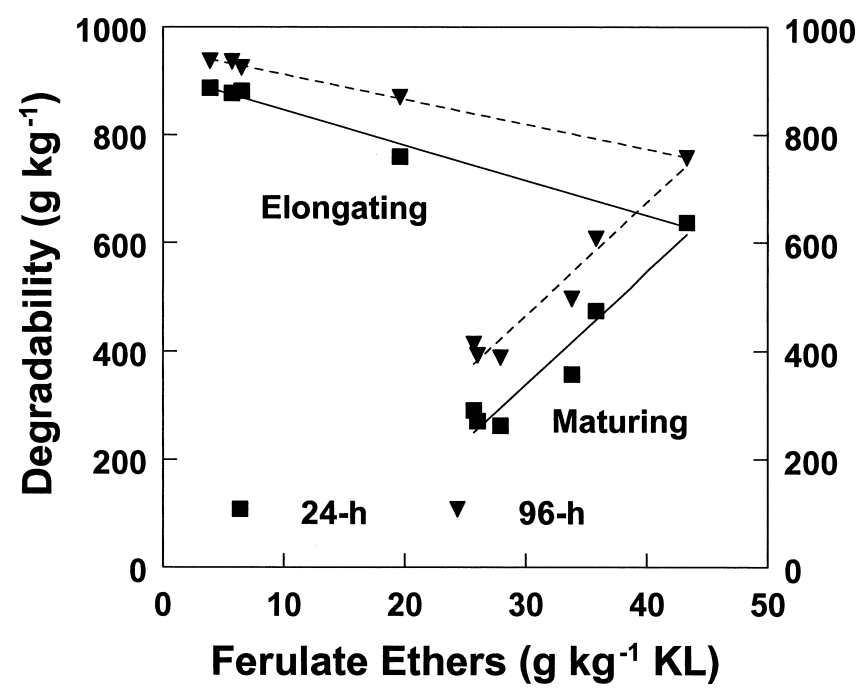

Fig. 6. The impact of ferulate ether cross-linking frequency with Klason lignin on total cell wall polysaccharide in vitro ruminal degradability of maize internodes sampled at 10 developmental stages. Data are means across three maize hybrids and two growth years. Linear regressions for degradability with ferulate/Klason lignin cross-linking frequency of elongating internodes (Sampling Dates 1 through 5: $24 \mathrm{~h}$ $\left.=952-3.59 \mathrm{X}, r^{2}=0.74 ; 96 \mathrm{~h}=989-2.60 \mathrm{X}, r^{2}=0.79\right)$ and postelongation internodes (Sampling Dates 5 through 10: $24 \mathrm{~h}=128+$ $\left.6.84 X, r^{2}=0.85 ; 96 h=261+6.69 X, r^{2}=0.82\right)$ were calculated.

phase when cells were growing in size and depositing primary wall material (Jung and Casler, 2006). If ferulate esters act as the nucleation site where lignin polymerization begins in the cell wall, as suggested by Ralph et al. (1995), then a high concentration of ferulate esters in the primary wall would allow lignin polymerization to develop at frequent intervals within the primary wall. The presence of many lignin macromolecules crosslinked by ferulates to arabinoxylan could provide sufficient physical coverage of the primary wall polysaccharides to prevent their degradation by rumen microbes. While Jung and Deetz (1993) suggested that ferulates might only be deposited in the primary walls of grasses, it was clearly shown that at least half of all the ferulate monomers (and presumably diferulates) were deposited in the secondary wall of maize internodes post-elongation (Jung, 2003). However, the concentration of ferulates was lower in the thick secondary cell walls deposited in post-elongation maize internodes (Morrison et al., 1998; Jung and Casler, 2006). This lower concentration of ferulates in the secondary wall, combined with the greater lignin deposition rate, may result in a lower frequency of ferulate/lignin cross-links that may be more widely spaced in the secondary wall. The individual lignin macromolecules may be larger in the secondary wall, based on the reduced ferulate ether concentration relative to Klason lignin, but the lignin may not be spatially associated with cell wall polysaccharides in such a way as to prevent access of the microbial polysaccharidases to their substrates.

\section{CONCLUSIONS}

As expected, degradability of maize stem internode tissues and cell wall polysaccharides declined during 
development. Just as previously reported for alfalfa stems, maize tissues remained completely degradable as long as they were not lignified. Only the ring structures in protoxylem vessels were lignified in elongating maize internodes, whereas virtually every maize stem tissue incorporated lignin into the wall during the postelongation secondary wall deposition. Unlike alfalfa, maize stem tissues that developed thick, lignified secondary walls remained partially degradable. Degradability of all maize cell wall polysaccharide components declined post-elongation, although the most abundant polysaccharide residues (glucose and xylose) were more severely affected by development than some of the minor sugar residues. Klason lignin concentration was negatively correlated with cell wall polysaccharide degradability, even though lignified secondary walls were partially degradable. The reduced frequency of ferulatemediated cross-linking of lignin to arabinoxylan in secondary walls compared to the primary wall may account for the greater degradability of secondary walls in lignified maize tissues.

\section{REFERENCES}

Ahmed, A.E.R., and J.M. Labavitch. 1977. A simplified method for accurate determination of cell wall uronide content. J. Food Biochem. 1:361-365.

Casler, M.D., and H.G. Jung. 1999. Selection and evaluation of smooth bromegrass clones with divergent lignin and etherified ferulic acid concentration. Crop Sci. 39:1866-1873

Engels, F.M. 1989. Some properties of cell wall layers determining ruminant digestion. p. 80-87. In A. Chesson and E.R. Orskov (ed.) Physico-chemical characterization of plant residues for industrial and feed use. Elsevier Applied Science, London.

Galyean, M.L., and A.L. Goetsch. 1993. Utilization of forage fiber by ruminants. p. 33-71. In H.G. Jung et al (ed.) Cell wall structure and digestibility. ASA, CSSA, and SSSA, Madison, WI

Grabber, J.H., R.D. Hatfield, and J. Ralph. 1998a. Diferulate crosslinks impede the enzymatic degradation of non-lignified maize walls. J. Sci. Food Agric. 77:193-200.

Grabber, J.H., R.D. Hatfield, J. Ralph, J. Zon, and N. Amrheins. 1995. Ferulate cross-linking in cell walls isolated from maize cell suspensions. Phytochemistry 40:1077-1082.

Grabber, J.H., J. Ralph, and R.D. Hatfield. 1998b. Ferulate cross-links limit the enzymatic degradation of synthetically lignified primary walls of maize. J. Agric. Food Chem. 46:2609-2614.

Gressel, J., Y. Vered, S. Bar-Lev, O. Milstein, and H.M. Flowers. 1983. Partial suppression of cellulase action by artificial lignification of cellulose. Plant Sci. Lett. 32:349-353.

Hatfield, R.D., H.G. Jung, J. Ralph, D.R. Buxton, and P.J. Weimer. 1994. A comparison of the insoluble residues produced by the Klason lignin and acid detergent lignin procedures. J. Sci. Food Agric. 65:51-58.
Iiyama, K., T.B.T. Lam, and B.A. Stone. 1990. Phenolic acid bridges between polysaccharides and lignin in wheat internodes. Phytochemistry 29:733-737.

Jung, H.G. 2003. Maize stem tissues: Ferulate deposition in developing internode cell walls. Phytochemistry 63:543-549.

Jung, H.G., and D.R. Buxton. 1994. Forage quality variation among maize inbreds: Relationships of cell-wall composition and in vitro degradability for stem internodes. J. Sci. Food Agric. 66:313-322.

Jung, H.G., and M.D. Casler. 2006. Maize stem tissues: Cell wall concentration and composition during development. Crop Sci. 46(4): 1793-1800.

Jung, H.G., and D.A. Deetz. 1993. Cell wall lignification and degradability. p. 315-346. In H.G. Jung et al (ed.) Forage cell wall structure and digestibility. ASA, CSSA, and SSSA, Madison, WI, USA.

Jung, H.G., and F.M. Engels. 2002. Alfalfa stem tissues: Cell-wall deposition, composition, and degradability. Crop Sci. 42:524-534.

Jung, H.G., T.A. Morrison, and D.R. Buxton. 1998. Degradability of cell-wall polysaccharides in maize internodes during stalk development. Crop Sci. 38:1047-1051.

Jung, H.G., and J. Ralph. 1990. Phenolic-carbohydrate complexes in plant cell walls and their effect on lignocellulose utilization. p. 173182. In D.E. Akin et al (ed.) Microbial and plant opportunities to improve lignocellulose utilization by ruminants. Elsevier, New York.

Littel, R.C., G.A. Milliken, W.W. Stroup, and R.D. Wolfinger. 1996 SAS systems for mixed models. SAS Inst., Cary, NC.

McDougall, I.M. 1948. Studies on ruminant saliva: I. the composition and output of sheep's saliva. Biochem. J. 42:99-109.

Moore, K.J., and R.D. Hatfield. 1994. Carbohydrates and forage quality. p. 229-280. In G.C. Fahey et al (ed.) Forage quality, evaluation, and utilization. ASA, CSSA, and SSSA, Madison, WI.

Morrison, T.A., H.G. Jung, D.R. Buxton, and R.D. Hatfield. 1998. Cellwall composition of maize internodes of varying maturity. Crop Sci. $38: 455-460$

Morrison, T.A., J.R. Kessler, R.D. Hatfield, and D.R. Buxton. 1994. Activity of two lignin biosynthesis enzymes during development of a maize internode. J. Sci. Food Agric. 65:133-139.

Ralph, J., J.H. Grabber, and R.D. Hatfield. 1995. Lignin-ferulate crosslinks in grasses: Active incorporation of ferulate polysaccharide esters into ryegrass lignins. Carbohydr. Res. 275:167-178.

Ralph, J., R.F. Helm, S. Quideau, and R.D. Hatfield. 1992. Ligninferuloyl ester cross-links in grasses. Part 1. Incorporation of feruloyl esters into coniferyl alcohol dehydrogenation polymers. J. Chem. Soc., Perkin Trans. 12961-2969.

Ralph, J., S. Quideau, J.H. Grabber, and R.D. Hatfield. 1994. Identification and synthesis of new ferulic acid dehydrodimers present in grass cell walls. J. Chem. Soc., Perkin Trans. 13485-3498.

Theander, O., P. Aman, E. Westerlund, R. Andersson, and D. Pettersson. 1995. Total dietary fiber determined as neutral sugar residues, uronic acid residues, and Klason lignin (The Uppsala Method): Collaborative study. J. AOAC Int. 78:1030-1044.

Wilson, J.R. 1993. Organization of forage plant tissues. p. 1- 32. In H.G. Jung et al (ed.) Forage cell wall structure and digestibility. ASA, CSSA, and SSSA, Madison, WI.

Wilson, J.R., and D.R. Mertens. 1995. Cell wall accessibility and cell structure limitations to microbial digestion of forage. Crop Sci. $35: 251-259$. 